\title{
A literatura religiosa polemista nas Índias Orientais seiscentistas e a elaboração da primeira tradução regular da Bíblia em língua portuguesa (1642-1694)
}

\author{
The polemist literature in seventeenth-century East Indies and \\ the first systematic translation of the Bible into the Portuguese \\ language (1642-1694)
}

Luis Henrique Menezes Fernandes*

\begin{abstract}
Resumo
Na segunda metade do século XVII, foram publicadas, nos domínios holandeses orientais, algumas edições de um panfleto intitulado Differença d'a Christandade. Esse "livrinho", carregado de ataques ao papado romano, materializava-se como representação literária exemplar dos constantes embates doutrinários travados entre católicos e protestantes, desde o alvorecer da Idade Moderna, na Europa Ocidental e, posteriormente, nos seus domínios ultramarinos. Por trás de sua divulgação, estava um até então desconhecido calvinista português - João Ferreira A. d'Almeida (1628-1691) -, ministro pregador da Igreja Reformada Holandesa, cujo nome, porém, tornar-se-ia bastante conhecido graças ao seu pioneiro trabalho de tradução da Bíblia em língua portuguesa. Almeida também produziu, ao longo de sua vida, várias outras obras, a maioria delas de caráter polemista anticatólico. Diante desses ataques à Igreja de Roma, três missionários católicos no Oriente - o agostiniano Jerônimo da Siqueira, o jesuíta Jean-Baptiste Maldonado e, posteriormente, o franciscano Giovan Battista Morelli - se levantaram contra as "heresias" do calvinista português. No âmago desse embate, foram produzidas algumas obras literárias polemistas, que apresentaremos sucintamente neste artigo, objetivando evidenciar as especificidades do embate religioso relativo à elaboração da primeira Bíblia em língua portuguesa. Assim, amparados em uma perspectiva histórico-religiosa, poderemos apontar a maneira como esse conflito doutrinário, a princípio intraeuropeu, se manifestou de forma sui generis em um novo contexto espacial e cultural, trazendo consigo não apenas singulares produtos doutrinais, mas também missiológicos e literários.
\end{abstract}

Palavras-chave: Conflitos religiosos. Tradução da Bíblia. Índias Orientais. Século XVII.

* Doutorando pelo Programa de Pós-Graduação em História Social da Universidade de São Paulo (FFLCHUSP). Pesquisa financiada pela FAPESP.E-mail: menezesfernandes@gmail.com 
A literatura religiosa polemista nas Índias Orientais seiscentistas e a elaboração ...

\begin{abstract}
During the second half of the seventeenth century, a few copies of a pamphlet entitled "Differença d'a Christandade" were published in the Dutch Colonies of East Indies. This "little book, full of attacks against Roman papacy, symbolized an exemplary written representation of the constant doctrinal struggles which occurred between Catholics and Protestants, since the Early Modern Age, in Western Europe, and later, in its overseas settlements. Behind its publication, was a (until then) unknown Portuguese Calvinist-João Ferreira A. d'Almeida (1628-1691)-, a minister and preacher of the Dutch Reformed Church, whose name, however, would become quite well known because of his pioneering work on Bible translation into Portuguese. He also wrote, during his lifetime, several other works, most of them against Catholicism. In light of these attacks on the Church of Rome, three Catholic missionaries in the East - the Augustinian Jerônimo da Siqueira, the Jesuit Jean-Baptiste Maldonado and, subsequently, the Franciscan Giovan Battista Morelli - defended the Catholic orthodoxy against the "heresies" of the Calvinist Portuguese. At the heart of this confrontation, some literary works were produced, which are the main sources that we shall analyze, aiming to understand the particularities of the religious confrontation behind the development of the first Bible in Portuguese. Therefore, using the methodology of the Italian School of History of Religions, we will be able to demonstrate how this doctrinal conflict, initially confined in Europe, manifested itself in a singular way in a new spatial and cultural context, bringing not only singular doctrinal results, but also literary and missiological
\end{abstract}

Keywords: Religious conflicts. Bible Translation. East Indies. 17th Century.

Ao longo da segunda metade do século XVII, foram publicadas em Batávia (atual Jacarta, capital da Indonésia) - antiga sede administrativa da Companhia Holandesa das Índias Orientais - algumas edições de um panfleto em língua portuguesa, que levava o seguinte título:Differença d'a Christandade, em que claramente se manifesta a grande disconformidade entre a verdadeira e antiga doctrina de Deus e a falsa e nova d'os homens. ${ }^{1}$ Esse "livrinho", carregado de veementes ataques ao papado romano, materializava-se enquanto representação literária exemplar dos permanentes embates doutrinários travados entre católicos e protestantes, desde o alvorecer da Idade Moderna, na Europa Ocidental e, posteriormente, nos seus domínios ultramarinos. Assim, esse escrito polemista, publicado em uma conjuntura de expansão do

${ }^{1}$ Fac-símile da segunda edição disponível em MATOS, Manuel Cadafaz de (ed.). Uma edição de Batávia em português do ultimo quartel do século XVII. Lisboa: Edições Távola Redonda, 2002. 
Império Holandês no Oriente - graças às repetidas investidas perpetradas desde princípios do século XVII contra as possessões portuguesas -, consistia em um eloquente discurso apologético da Reforma protestante, elaborado em direta oposição à ortodoxia doutrinária católica, firmada e reafirmada no Concílio de Trento (1545-1563).

$\mathrm{O}$ fato, à primeira vista curioso, de haver sido publicado em língua portuguesa, apesar de impresso em território holandês no Oriente, se justifica, em primeiro lugar, pela importância global adquirida por esse idioma nas chamadas "Índias Orientais", mesmo em um período em que Portugal perdia a primazia diante da abrupta ascensão dos holandeses (os quais, por vezes, obstinadamente, tentaram, em vão, extinguir a língua portuguesa de seus domínios coloniais). ${ }^{2}$ Além disso, o panfleto apologético da Reforma fora traduzido, anotado e impresso sob os auspícios de um até então desconhecido calvinista português - João Ferreira A. d'Almeida (1628-1691) -, ministro pregador da Igreja Reformada Holandesa da comunidade de língua portuguesa em Batávia, na ilha de Java. O seu nome, porém, permaneceria inexoravelmente associado ao pioneiro trabalho de tradução das Escrituras Sagradas do cristianismo para a língua portuguesa. ${ }^{3}$

Em 1681, Almeida viu o primeiro fruto do seu trabalho como tradutor das Escrituras sair à luz, com a publicação, em Amsterdam, do primeiro Novo Testamento completo em língua portuguesa. ${ }^{4}$ No ano em que faleceu, havia traduzido quase a totalidade do Velho Testamento, mas deixou o trabalho inacabado até os versículos finais das profecias de Ezequiel. A tradução dos demais livros do Velho Testamento foi finalizada, em 1694, por outro ministro da Igreja Reformada Holandesa, companheiro de Almeida na comunidade de

\footnotetext{
${ }^{2}$ Sobre esse fenômeno linguístico, Charles R. Boxer aponta que, "uma vez que a expansão da Europa foi iniciada pelos portugueses, a língua portuguesa (ou uma adaptação dela) tornou-se a língua franca da maioria das regiões costeiras que eles abriram ao comércio e aos empreendimentos europeus em ambos os lados do globo. Por ocasião do confronto com os holandeses, a língua portuguesa já criara raízes demasiado profundas para ser erradicada, mesmo nos domínios coloniais em que os holandeses tentaram substituí-la". BOXER, C. O império marítimo português. São Paulo: Companhia das Letras, 2002. p. 140. Sobre esse mesmo assunto, cf. LOPES, D. Expansão da Língua Portuguesa no Oriente. Lisboa: Aliança Nacional das A.C.M.s de Portugal, 1979.

${ }^{3}$ Sobre a primazia de João Ferreira de Almeida na tradução da Bíblia para a língua portuguesa, cf. SANTOS, A. R. dos. "Memorias sobre algumas traduccções, edições biblicas menos vulgares em lingua portuguesa, especialmente sobre as obras de João Ferreira de Almeida". In: Memorias de litteratura portugueza, Tomo VII. Lisboa: Academia Real das Sciencias, 1806, p. 17-59.

${ }^{4}$ O Novo Testamento, isto he, Todos os Sacro Santos Livros e Escritos Evangelicos e Apostolicos do Novo Concerto de nosso Fiel Senhor Salvador e Redemptor IESU CHRISTO. Agora traduzido en Portugues Pelo Padre João Ferreira A d'Almeida, Ministro Pregador do Sancto Evangelho. Em Amsterdam: Por viuva de J. V. Someren. Anno 1681. Exemplar disponível na Biblioteca Nacional de Portugal.
} 
língua portuguesa de Batávia: o holandês Jacob op den Akker. Entretanto, a tradução completa do Velho Testamento foi publicada pela primeira vez somente em meados do século XVIII, pela imprensa tipográfica de Batávia e pelos missionários dinamarqueses luteranos de Tranquebar.

Além da tradução da maior parte da Bíblia e da publicação do tratado sobre a Differença d'a Christandade, João Ferreira de Almeida também produziu, ao longo de sua vida, várias outras obras, a maioria delas de caráter catequético/apologético do protestantismo. Em 1650, traduziu para a língua portuguesa o Catecismo de Heidelberg e a Liturgia da Igreja Reformada. Na mesma década, revisou a tradução portuguesa de As fábulas de Esopo, impressa somente em 1672. Ainda nesse mesmo ano, publicou um conjunto de escritos polemistas composto de duas longas epístolas e vinte propostas contra a Igreja Católica, dirigidas estas últimas "a todos os eclesiásticos do Reino e Senhorios de Portugal”. No ano seguinte, publicou a tradução holandesa do tratado Differença d'a Christandade, com o título Onderscheydt der Christenheydt. Por fim, escreveu também um apêndice ao texto Differença d'a Christandade, reafirmando sua convicção de que somente a Igreja Católica "muda, transtorna, corrompe e falsifica os fundamentos da doutrina cristã".

Em todos os seus escritos apologéticos, João Ferreira de Almeida busca refutar, com base em sua própria tradução das Escrituras Sagradas em língua portuguesa, os dogmas centrais do catolicismo pós-tridentino, citando para isso, com frequência, o próprio Catecismo Romano - produzido por ordem do Concílio de Trento e publicado pela primeira vez na Itália em 1566 -, bem como outros textos catequéticos dele derivados, especialmente a Doutrina Cristã, do jesuíta Marcos Jorge, a Declaração Copiosa da Doutrina Cristã, do jesuíta italiano Roberto Bellarmino e o Catecismo ou Doutrina Cristã e Práticas Espirituais, do frei dominicano Bartolomeu dos Mártires, todos de grande circulação em Portugal e em suas colônias ultramarinas. Desse modo, embora tenha passado a maior parte de sua vida nos domínios holandeses orientais, lutou pela propagação da doutrina reformada em Portugal e em suas conquistas ultramarinas, seja por meio da divulgação das Escrituras em língua vulgar, seja por meio da publicação de seus escritos apologéticos da Reforma protestante.

Diante dessa conjuntura de fortes ataques à ortodoxia doutrinária da Igreja Romana, três clérigos regulares católicos, missionários no Oriente, se levantaram decididamente contra o discurso agressivo e as doutrinas heterodoxas do calvinista português. Primeiramente, o frade agostiniano Jerônimo da Siqueira, também português, publicou, em 1670, em Bengala, 
uma Carta apologética em defensão da religião católica romana contra João Ferreira de Almeida, na qual apresentou muitos ataques ao herege "predicante da seita calvinista", denunciando não somente a deformidade de sua doutrina, mas também de seu caráter. ${ }^{5}$ Nesse mesmo período, houve contendas teológicas envolvendo João Ferreira de Almeida e outro clérigo católico: o belga Jean-Baptiste Maldonado, missionário da Companhia de Jesus, que passou por Batávia no ano de 1667. A partir desse choque teológico-doutrinário, foi publicada uma extensa obra literária, organizada em forma de diálogo, intitulada Diálogo Rústico e Pastoril entre o cura de uma aldeia e um pastor de ovelhas, cuja autoria é tradicionalmente atribuída ao missionário jesuíta. ${ }^{6}$

Da mesma forma, embora já em um período subsequente, o italiano Giovan Battista Morelli, missionário apostólico da Ordem de São Francisco, escreveu no ano de 1708, em São Tomé de Meliapor (antiga possessão lusitana situada na costa do Coromandel, sudeste da Índia), a obra Luzeiro Evangélico, que mostra a todos os cristãos das Índias Orientais o caminho único, seguro e certo da reta fé, para chegarem ao porto da salvação eterna. Produzido especificamente para contradizer as publicações portuguesas apologéticas da Reforma protestante que circulavam abundantemente nas Índias Orientais, o autor do Luzeiro Evangélico, escrevendo também em português, cita repetidas vezes o tradutor calvinista e algumas de suas obras (inclusive sua tradução pioneira do Novo Testamento), reprovando-as todas com grande veemência, com base na ortodoxia católica romana pós-tridentina. ${ }^{7}$

Assim, supomos que somente a partir de uma análise acurada das obras polemistas, apologéticas e catequéticas mencionadas, relativas ao embate teológico subjacente ao processo de elaboração da primeira versão regular da Bíblia em língua portuguesa, será possível compreender historicamente, de fato, o significado desse singular procedimento de tradução. A bibliografia existente sobre o surgimento da primeira Bíblia em língua portuguesa, não obstante sua excelência em muitos sentidos, é caracterizada pela ausência de um estrito rigor historiográfico. Essa ausência significa, antes de tudo,

${ }^{5}$ Carta Apologetica em defenção da Religião Catholica Romana contra João Ferreira de Almeida, predicante da secta calvinista, feita em Bangalla pello muito Reverendo Pe. Hieronymo de Siqueira, Portugues Theologo Pregador. Anno? 1670. [manuscrito] Exemplar existente no Arquivo Nacional da Torre do Tombo.

${ }^{6}$ Diálogo Rústico e Pastoril entre o cura de uma aldeia e um pastor de ovelhas... Amsterdam: c. 1684. Exemplar disponível na Biblioteca Nacional da Holanda (Haia).

${ }^{7}$ Luzeiro Evangelico, Que mostra à todos os Christãos das Indias orientais o caminho vnico, seguro, \& certo da recta Fè, para chegarem ao porto da salvação eterna... Escrita em S. Thome das Indias orientais. Anno de 1708 \& impressa em Mexico, Cidade da India occidental. Anno de 1710. Exemplar disponibilizado pela Biblioteca Mário de Andrade. 
que os seus três principais representantes - nomeadamente António Ribeiro dos Santos, Jan L. Swellengrebel e Herculano Alves - encaminharam suas pesquisas e reflexões não no sentido de proporcionar um enquadramento solidamente histórico do significado desse processo ímpar de tradução, mas principalmente para construir biografias lineares sobre o seu principal idealizador - João Ferreira A. d'Almeida -, bem como para elencar sistematicamente as inúmeras edições publicadas, ao longo dos últimos séculos, dessa pioneira tradução regular da Bíblia em língua portuguesa. ${ }^{8}$

A ausência de uma perspectiva historicamente fundada, que caracteriza em maior ou menor medida essa produção bibliográfica, não impediu que seus autores fornecessem excelentes contribuições sobre o assunto, proporcionando abordagens originais, críticas e instigantes, fundamentais para servir como ponto de partida para outras pesquisas sobre o mesmo tema. ${ }^{9}$ Ainda assim, a carência de uma visão de fato histórica a respeito dessa tradução específica - ou seja, que vinculasse solidamente os problemas específicos do objeto aos principais debates historiográficos concernentes, direta ou indiretamente, ao seu contexto - trouxe como um de seus principais sintomas o deslocamento das fontes primárias do centro de suas indagações. Assim, embora esses autores conheçam parcialmente a literatura religiosa polemista produzida no ambiente em que João Ferreira de Almeida empreendeu seu trabalho de tradução, suas análises não privilegiaram o conteúdo desses escritos seiscentistas.

Logo, é notável que a bibliografia produzida especificamente sobre o contexto de tradução das Escrituras Sagradas em língua portuguesa careça de uma maior profundidade analítica e de uma problematização histórica mais densa. Essa "defasagem" historiográfica - diante das ricas fontes primárias disponíveis - decorre, primeiramente, do fato de não haver sido dada

\footnotetext{
${ }^{8}$ Cf. SANTOS, op. cit., SWELLENGREBEL, J. L.; HALLOCK, E. F. (ed.). A maior dádiva e o mais precioso tesouro: a biografia de João Ferreira de Almeida e a história da primeira Bíblia em português. Rio de Janeiro: JUERP, 2000. ALVES, H. A Bíblia de João Ferreira Annes d'Almeida. Lisboa: Sociedade Bíblica, 2007.

${ }^{9}$ Além dos três autores supracitados, outros pesquisadores se dedicaram à mesma temática, mas não trouxeram, a nosso ver, contribuições decisivas ao seu entendimento, de modo que seus trabalhos se destinaram basicamente a preencher pontualmente algumas lacunas biográficas ou tipográficas deixadas por Ribeiro dos Santos. Como exemplo, podemos mencionar as obras de SILVA, I. F. da. Diccionario bibliographico portuguez, vol. III. Lisboa, 1859, p. 368-372. RIVARA, J. H. da C. “João Ferreira de Almeida e a sua Traducção Portugueza da Bíblia”. o Chronista de Tissuary, vol. I, n. 3, Nova Goa: Imprensa Nacional, 1866, p. 75-84. FERREIRA, G. L. S. A Biblia em Portugal: apontamentos para uma monografia (1495-1850). Lisboa: Tipografia de Ferreira de Medeiros, 1906 e AZEVEDO, P. de. "O calvinista português, Ferreira de Almeida”. Boletim da Segunda Classe - Academia de Ciências de Lisboa. vol. XII, fasc. 2, Coimbra: Imprensa da Universidade, 1919.
} 
a devida ênfase à relação intrínseca existente entre o processo histórico de elaboração da primeira tradução da Bíblia em português e os conflitos doutrinários católico-calvinistas a ele subjacentes, manifestos abundantemente nos diversos escritos polemistas vinculados diretamente ao ambiente da tradução. Além desse aspecto evidente - ou melhor, como decorrência dele -, a historiografia acabou não analisando com a atenção necessária as diversas fontes relacionadas ao tema, todas indispensáveis ao seu satisfatório entendimento histórico.

Diante do exposto, supomos que a formação da primeira tradução da Bíblia em língua portuguesa, em sua singularidade e importância histórica, não poderá ser satisfatoriamente compreendida se não forem analisados de forma rigorosa os diversos escritos polemistas relacionados diretamente ao contexto de sua elaboração (os quais, como já apontamos, permanecem explorados apenas de modo superficial pela bibliografia especializada). Nesse sentido, visando uma compreensão histórica aprofundada da tradução bíblica de João Ferreira de Almeida no Oriente seiscentista, torna-se indispensável realizar análise minuciosa dos conflitos católico-calvinistas subjacentes ao processo de sua elaboração, com especial ênfase nas suas particularidades relativas ao ambiente histórico singular em que foram produzidas.

A documentação relativa ao contexto de elaboração da primeira Bíblia em língua portuguesa, apresentada sucintamente acima, demonstra que esse trabalho de tradução, iniciado por João Ferreira de Almeida nas Índias Orientais a partir do ano de 1642, não se resume a um esforço meramente literário de divulgação das Escrituras judaico-cristãs em língua vulgar, mas é, sobretudo, parte integrante de toda uma postura religiosa, espiritual e missiológica diante do mundo de sua época, destinada especialmente (mas não exclusivamente) à sociedade portuguesa católica do século XVII. Pode-se apreender isso pela leitura do prefácio escrito pelo próprio João Ferreira de Almeida, em 1668, a sua tradução do tratado Differença da Christandade. Nesse prólogo, intitulado "ao discreto leitor", Almeida dirige-se explicitamente:

A todos os senhores católicos romanos da nação portuguesa, de qualquer estado, qualidade e condição que sejam, com todos os demais que da língua portuguesa usam, e juntamente deveras desejam e procuram sua salvação. ${ }^{10}$

Nesse mesmo prefácio, podemos encontrar grande parte das informações sobre a passagem de João Ferreira de Almeida à Igreja Reformada

${ }^{10}$ Differença d'a Christandade... p. 19. In: MATOS, op. cit. 
Holandesa, em 1642, justamente a partir da leitura desse folheto escrito originalmente em língua castelhana, cuja autoria original tem gerado dúvidas e hipóteses entre os especialistas supracitados. 0 propósito de tradução desse "livrinho" em língua portuguesa seria possibilitar, segundo João Ferreira de Almeida, a "conversão e salvação dos que outra nenhuma língua sabem, senão a portuguesa", enquanto não houvesse tradução das próprias Escrituras Sagradas nesse idioma. ${ }^{11}$ Assim, portanto, os esforços de Almeida na divulgação da doutrina da Igreja Reformada em língua portuguesa - esforço este que engloba todo o seu trabalho de tradução das Escrituras - destinava-se, como vimos, não somente ao Reino de Portugal, mas também às populações de língua portuguesa que habitavam as Índias Orientais naquele período, especialmente os fiéis católicos romanos. Nesse mesmo prefácio, o tradutor português apresenta sua indignação diante da situação do Reino de Portugal em relação a essa matéria:

Que seja possível que não haja já hoje, em toda a nossa Europa, a mínima nação, que em sua própria língua tenha já impressa toda a Escritura Sagrada, e que só a portuguesa não tenha ainda, na sua, impresso nem um só evangelho? E só ela, entre tantas, careça de um tamanho, inefável, incompreensível e salutário bem! Que seja esta nação, em tudo o demais, uma das primeiras e principais, e no que, sobretudo, mais lhe importa, chegue a tanta miséria, que ela só venha a ser a última e ínfima! Que todas as outras dêem entrada e abram os olhos a esta divina luz, e que só esta, tão pertinazmente, lhe resista e se lhe oponha! ${ }^{12}$

Em seguida, vemos João Ferreira de Almeida tratando do seu propósito pessoal de tradução da Bíblia em português - trabalho por ele iniciado já em 1642, ano de sua conversão ao cristianismo reformado, contando com apenas quatorze anos de idade -, dando-lhe todo o significado espiritual e sagrado que desejamos enfatizar nesse momento:

[Por enquanto], vos podeis servir e ajudar da versão castelhana [da Bíblia], uma das melhores que, até o presente, tenha saído à luz, [...] até que, mediante o divino favor, acabe de alimpar, e bem conferir com o texto original, uma tradução do Novo Testamento que, já vai por alguns anos, tenho preparada. $\mathrm{E}$, o mais presto que puder, pretendo fazer sair à luz. Como também (dandome Deus, nosso Senhor, vida, tempo e saúde), com todas minhas forças, ainda que bem poucas (que, enfim, quando os homens calam, faz Deus que as pedras falem), espero, em poucos anos, fazer o mesmo com o Velho [Testamento], e dar-vos, assim, em breve, toda a Escritura Sagrada em vossa própria língua. Que é a maior dádiva, e o mais precioso tesouro, que nunca ninguém, que eu saiba, até o presente, vos tenha dado. ${ }^{13}$

\footnotetext{
${ }^{11}$ Ibidem, p. 10.

${ }^{12}$ Ibidem, p. 25-26.

${ }^{13}$ Ibidem, p. 26-27, grifo nosso.
} 
É possível, portanto, perceber que tentar reduzir a compreensão histórica do processo de formação dessa primeira tradução completa dos textos bíblicos em língua portuguesa aos seus aspectos sociais, literários ou políticos, por exemplo, constituiria indevida simplificação da matéria, desviando o objeto analisado de seu aspecto central: os conflitos religiosos a ele subjacentes e, desse modo, circunscritos ao domínio autônomo da perspectiva histórico-religiosa. Em outros termos, intentamos demonstrar como a compreensão histórica desse processo não poderá ser atingida senão sob uma perspectiva histórico-religiosa, ou seja, que confira aos fatos religiosos a irredutibilidade necessária à compreensão de processos tão complexos. Por conseguinte, a tradução das Escrituras Sagradas do cristianismo por João Ferreira de Almeida, sendo compreendida como um acontecimento eminentemente religioso - e não simplesmente literário, filosófico, moral, político etc. - deverá ser analisada, nesse caso, historicamente, como uma resposta "religiosa" a uma conjuntura "religiosa".

Essa postura teórica advém, por seu turno, dos pressupostos metodológicos delineados pelos autores da chamada Escola Italiana de História das Religiões, cujo momento fundante é a publicação, em 1925, do primeiro número da revista Studi e Materiali di Storia delle Religioni, sob a direção do historiador das religiões italiano Raffaele Pettazzoni (1883-1959). Essa perspectiva histórico-religiosa propõe, por um lado, o desenvolvimento da disciplina História das Religiões enquanto domínio autônomo no campo historiográfico - isto é, não como tema subsidiário da História Social, Econômica ou Cultural, por exemplo -, com o fim de proporcionar a devida complexificação da matéria. Por outro lado, seus autores defendem a necessidade de trabalhar historicamente não apenas o objeto "religioso" em si, mas também, e sobretudo, as próprias categorias epistemológicas utilizadas pelo historiador na construção de sua análise. ${ }^{14}$

No tocante aos nossos escritos polemistas em foco, e no que tange a sua particularidade histórica, pode-se notar que o contexto espacial em que esses conflitos tomaram corpo (as então chamadas "Índias Orientais")

\footnotetext{
${ }^{14}$ Outros representantes dessa perspectiva, juntamente com Pettazzoni, são, primeiramente, Angelo Brelich e Ernesto De Martino, bem como, mais recentemente, Dario Sabbatucci, Nicola Gasbarro, Marcello Massenzio, Vittorio Lanternari e Gilberto Mazzoleni. No Brasil, destacam-se nessa metodologia os professores Adone Agnolin (USP) e Maria Cristina Pompa (UNIFESP). Para uma visão global dos fundamentos teóricos da Escola Italiana de História das Religiões, cf. MASSENZIO, M. A história das religiões na cultura moderna. São Paulo: Hedra, 2005; AGNOLIN, A. O debate entre história e religião em uma breve história da História das Religiões: origens, endereço italiano e perspectivas de investigação. Projeto História, São Paulo, n. 37, jul. 2008, p. 13-39.
} 
incidiu sobre eles de maneira expressiva, tornando-os singulares em termos doutrinários, literários e missiológicos. A proximidade geográfica desse choque doutrinal em relação à alteridade cultural do Oriente luso-holandês e suas circunvizinhanças (especialmente em relação aos povos nativos da ilha de Java, de Ceilão, da Índia, da China e do Japão) levou os contendores religiosos europeus a compreendê-la - após absorverem sub specie religionis as culturas locais, ou seja, interpretá-las de acordo com seu particular código ocidental de "religião" - pelo prisma privilegiado do embate doutrinário no qual estavam de todo inseridos. Nessa conjuntura delicada, teriam sido produzidos não somente os escritos polemistas já delineados, mas também a própria tradução pioneira da Bíblia em língua portuguesa.

Nesse contexto, os religiosos católicos e protestantes protagonizaram, em certo sentido, uma verdadeira transformação simbólica das culturas locais, traduzindo-as e instrumentalizando-as para reafirmar e readequar suas posições teológicas preestabelecidas em suas respectivas ortodoxias. No tratado sobre a Differença d'a Christandade, por exemplo, João Ferreira de Almeida equipara as cerimônias católicas aos ritos chineses e japoneses, reduzindo-os ambos à mais "pura gentilidade" e a "uma mera, abominável e gentílica idolatria". ${ }^{15}$ De maneira mais expressiva, afirmava que, "quem for à China e ao Japão, pode bem coligir quão grande conveniência tenha a missa com as cerimônias e superstições ridículas e idolátricas daquelas partes, e de toda a demais gentilidade". ${ }^{16}$ Por fim, reafirmando sua comparação depreciativa, o tradutor calvinista se referia ao "tão notório e abominável exemplo de Dom Vasco da Gama e seus companheiros, quando foram a descobrir a Índia":

\begin{abstract}
pois entrando em Calicute num pagode dos gentios, se ajoelharam e adoraram aos ídolos que nele estavam, cuidando que eram imagens a seu modo, ou, para melhor dizer, ídolos à romanesca, tanta é a semelhança que entre uns e outros há, e tanta a conformidade entre as cerimônias e superstições gentílicas e as romanas [...]. A mesma semelhança se acha também entre a uma e a outra idolatria, assim dos infiéis gentios, como dos cegos e pertinazes papistas, entre os ídolos de uns e de outros, e o modo e maneira de os adorar, servir e festejar; assim em Europa, como em ambas as Índias, Orientais e Ocidentais. E o mesmo engano tem também sucedido a outros muitos portugueses e mais papistas em semelhantes ocasiões, particularmente na China e no Japão, aonde a semelhança é tanta, que a muitos faz ficar atônitos. ${ }^{17}$
\end{abstract}

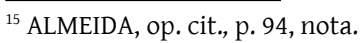

${ }^{16}$ Ibidem, p. 75, nota.

${ }^{17}$ Ibidem, p. 94-95.
} 
Assim, a alteridade cultural do Oriente encontrou um lugar epistemológico específico no conflito religioso subjacente à tradução da Bíblia em língua portuguesa. Do lado católico, da mesma forma, Jerônimo da Siqueira, em sua Carta Apologética contra João Ferreira de Almeida, fazia referências ignominiosas ao Islã, comparando repetidas vezes o tradutor calvinista ao seu profeta Maomé (que era chamado de Mafoma). No final de seu texto, Jerônimo de Siqueira estabelece um paralelo entre a biografia do profeta do Islã e a trajetória de Almeida, desde seu nascimento até a renegação da fé católica:

Porque o vejo na vida mui semelhante a Mafoma. Porque, se Mafoma foi precursor do anticristo, João Ferreira foi o que seus passos seguiu muito ao claro. [...] Aquele, amigo leitor, foi Mafoma; este é João Ferreira. Aquele, legislador da mais infame seita, e este, predicante da nefanda religião calvinística. ${ }^{18}$

As culturas locais, interpretadas sub specie religionis pelos contendores religiosos europeus, foram por eles reduzidas ao seu próprio universo religioso conflitivo, para, em seguida, serem traduzidas enquanto alvos privilegiados da atividade missionária reformista e contrarreformista, de acordo com as próprias especificidades de cada uma delas. Nesse contexto, portanto, a construção do pensamento europeu da alteridade cultural das Índias Orientais parece ter sido forjada sob o signo religioso da Cristandade em choque doutrinal, fazendo, assim, com que as outras culturas, a princípio ininteligíveis às categorias de análise disponíveis à cultura ocidental, fossem sendo traduzidas, nessa conjuntura de embates religiosos, em elementos estrategicamente inteligíveis e, por fim, subsidiários de um debate teológico-cristão anterior e por ele alvejado missiologicamente. Nessa perspectiva, presumimos que essas situações dialógicas culturais, inerentes ao contexto de elaboração da primeira tradução da Bíblia em língua portuguesa, são elementos-chave para proporcionar sua efetiva compreensão histórica.

Ainda no tratado sobre a Differença d'a Christandade, João Ferreira de Almeida estabelece repetidas comparações entre a missa católica e expressões como "feitiçarias", "encantamento" e "agouro". Em sua estrutura discursiva, as cerimônias católicas encontram-se, portanto, em um degrau abaixo da "religião", sendo aproximadas às magias do paganismo. Em seus próprios termos, o clero católico romano acabou, ao longo dos séculos, por "corromper e falsificar a sacrossanta e salutífera doutrina do Santo

${ }^{18}$ SIQUEIRA, op. cit., p. 148-149. 
Evangelho, convertendo-a e mudando-a, assim, em puros e meros agouros, superstições, feitiçarias e encantamentos". ${ }^{19}$ A aparência exterior da missa lhe parece elaborada para "entreter o povo em ignorância, superstição e idolatria, trazendo-o assim embebido, enguiçado e como que encantado e enfeitiçado com aquelas mostras de pompa exterior". ${ }^{20}$ Por fim, faz referência explícita à Eucaristia romana, ingressando no polêmico debate católico-protestante sobre a transubstanciação, ou seja, a realidade corporal de Jesus Cristo na missa:

o sacerdote papístico as fala com a hóstia e com o vinho no cálice, quase bocejando e bafejando sobre eles, como se os quisera aquentar; e falando-lhes, como por modo de encantamento, muito manso, e como em grande segredo, para assim, deste modo, a seu ver, os poder transubstanciar..$^{21}$

Há ainda, no fim da obra, um anexo bastante curioso, intitulado Corolário, no qual se estabelece uma equiparação, em forma de verso, entre o Papa e Maomé (a quem chama Mafoma, conforme a grafia da época). De fato, os elementos do Islã são instrumentalizados diversas vezes nesse embate, por ambos os lados, para defenderem suas posições doutrinárias e atacarem seus opositores. Nesse caso, não há referências ao autor do poema, que não podemos deixar de supor que seja o próprio João Ferreira de Almeida, pelo seu conteúdo polemista:

Pergunta.

Digam-me, pois, que diferença

Há entre o Papa e Mafoma?

Se, em Roma, em tanta eminência,

Se entroniza assim Sodoma!

Resposta.

Não há nenhuma, e há muita.

Mas parece contradiz?

Não: espremei esta fruta;

Sereis então bom juiz.

Conclusão Provante.

Nenhuma, pois alto prega

Roma inteira tudo isto.

\footnotetext{
${ }^{19}$ ALMEIDA, op. cit., p. $144-145$.

${ }^{20}$ Ibidem.

${ }^{21}$ Ibidem.
} 
Luis Henrique Menezes Fernandes

\section{Muita, pois Mafoma nega,}

E o Papa simula a Cristo. ${ }^{22}$

É interessante, para nossa proposta analítica, essa comparação estabelecida na parte final da Differença d'a Cristandade entre o Papa e Maomé, especialmente por intentar, primeiramente, aproximá-los, por sua comum resistência ao Evangelho das Escrituras Sagradas, mas também, em um segundo momento, afastá-los, sugerindo que cada um deles se afasta da verdade divina por caminhos particularizados. 0 tom é, assim, de franco ataque às doutrinas católicas, reafirmadas veementemente, no século anterior, pelo Concílio Tridentino.

Em relação às acusações de que os reformados seriam hereges, Almeida responde dizendo que "por heresia, não entendem [os católicos] outra coisa, senão a verdadeira, divina e antiga doutrina católica e apostólica cristã de nossas igrejas reformadas", as quais, segundo ele, "pela graça e misericórdia de Deus, nosso Senhor, já do papismo e do anticristianismo estão purgadas e purificadas". ${ }^{23}$ Há também, ao longo do texto, críticas à divisão, própria da Igreja Romana, entre clero e laicato - divisão rechaçada, desde o início, pelos pregadores da Reforma. Nos termos do próprio calvinista português:

Eles se atrevem a chamar leigos e seculares, isto é, profanos e mundanos, a todos os que não são eclesiásticos, frades ou sacerdotes, sendo que não há hoje maiores profanos e mundanos, nem maiores profanidades e mundanices no mundo, que entre os eclesiásticos, frades e sacerdotes da Igreja Romana. ${ }^{24}$

Como já mencionamos anteriormente, outro importante documento relativo a esse contexto de embates doutrinários, fundamental para a compreensão histórico-religiosa do processo de surgimento da Bíblia em português, é o texto intitulado Carta Apologetica em defenção da Religião Catholica Romana contra João Ferreira de Almeida, predicante da secta calvinista. ${ }^{25}$ Foi escrito por volta de 1670, pelo frade agostiniano Jerônimo de Siqueira, cujo nome verdadeiro seria Antônio Dias. Interessante notar, a partir da análise desse escrito, primeiramente, o fato de seu autor parecer desconhecer a relação entre João Ferreira de Almeida e seu propósito de tradução da Bíblia em língua portuguesa (até esse momento, não havia sido publicada ainda

\footnotetext{
${ }^{22}$ Ibidem, p. 199.

${ }^{23}$ ALMEIDA. Differença d'a Christandade... In: MATOS, op. cit., p. 46.

${ }^{24}$ Ibidem, p. 49-50.

${ }^{25}$ SIQUEIRA, op. cit.
} 
a primeira edição do Novo Testamento, de 1681, e as versões portuguesas neotestamentárias de Almeida circulavam apenas em versões manuscritas, especialmente em Malaca, Ceilão e Batávia).

O frade agostiniano se levanta, por um lado, contra o panfleto sobre a Differença d'a Christandade e, por outro, mais especialmente, contra uma carta de João Ferreira de Almeida - enviada a João Correia de Mesquita, fidalgo da Ordem de Cristo - sobre um encontro conflitivo entre ambos, que teria ocorrido em Batávia, em meados da década de 1660. Nesse encontro, marcado por intensos debates teológicos, conformepodemos coligir desse e de outros documentos analisados, o centro da controvérsia entre ambos foi a seguinte questão: é possível ou não aos homens guardar perfeitamente os preceitos de Deus?

A partir daí, a tônica do texto é uma tentativa de degradação, não apenas doutrinária, mas especialmente moral, do calvinista português e de seus correligionários. Segundo Siqueira, João Ferreira de Almeida "traz em sua carta a fábula tão mal composta, autorizada com vinho, como se os portugueses se criassem em tavernas, como hereges fazem, sendo estas suas escolas". ${ }^{26}$ Têm especial relevância, porém, para nossa análise, as comparações estabelecidas pelo agostiniano entre João Ferreira de Almeida e Maomé. Essa equiparação entre Islã e Reforma é bastante recorrente na documentação católica contra as doutrinas do cristianismo reformado. Do mesmo modo, como já demonstramos, João Ferreira de Almeida também instrumentalizou componentes da religião islâmica em seu discurso, utilizando-os, por sua vez, contra o catolicismo romano.

Por outro lado, Jerônimo de Siqueira estabelece também algumas relações entre as doutrinas reformadas e a chamada "obstinação judaica". Já no início de sua carta, pondera que "de hebreus a hereges, vai pouca diferença". ${ }^{27}$ Citando uma profecia do Antigo Testamento, escrita expressamente contra a Casa de Israel, Siqueira expressa que:

não só dos hebreus entendo eu essa profecia, mas também o desatino da calvinística seita o profeta com ela chora, porque igreja mais dissoluta, a que Vossas Mercês chamam reformada, não mostra só [em]enganar a fé de Cristo sua malícia, mas também em blasfemarem dela mostram sua pouca vergonha. ${ }^{28}$

\footnotetext{
${ }^{26}$ Ibidem, p. 42

${ }^{27}$ Ibidem, p. 5

${ }^{28}$ Ibidem.
} 
Assim, segundo seus argumentos, o que se diz dos hebreus no Velho Testamento, no tocante a sua desobediência aos preceitos divinos, exatamente o mesmo "se pode dizer dos da família calvinística, pois chamando a sua igreja 'reformada', são os mais ímpios na vida; na doutrina, os mais blasfemos; no político, os mais tiranos; e contra a divina lei, os mais cegos". ${ }^{29}$ Finalmente, Jerônimo de Siqueira acusa João Ferreira de Almeida, juntamente com toda a Igreja Reformada, de ateísmo, primeiramente, devido ao apego dos calvinistas aos seus escritos catequéticos - citando explicitamente o Catecismo de Heidelberg - e, também, ao não reconhecimento dos escritos deuterocanônicos do Velho Testamento. Conforme diz sua Carta Apologética, "os tais são ateus [...]; pois, repudiando a palavra de Deus, veneram como ídolos aos escritos humanos; [...] logo, não são só em dizerem que tudo e por tudo se sujeitam à Escritura, mas são ateus, pois, por admitir humanos escritos, a desprezarem". ${ }^{30}$

Em resposta a esses ataques frontais do agostiniano português, João Ferreira de Almeida publicou, em 1672, um conjunto de documentos relativos a esse encontro com Jerônimo de Siqueira em Batávia, incluindo a citada carta enviada a João Correia de Mesquita, na qual narra detalhadamente o que ocorrera naquela ocasião. Esse conjunto documental foi intitulado Duas Epistolas e Vinte Propostas. ${ }^{31}$ No que tange a nossa específica problemática, é interessante mencionar as referências que João Ferreira de Almeida faz nesse escrito, especialmente na carta dirigida aos "aos Reverendos Padres e Religiosos Agostinhos de Bengala", entre o que chama de idolatria gentílica e idolatria católica.

Em relação à primeira forma idolátrica, afirma que "tal era antigamente, e o é ainda o dia de hoje, a idolatria dos gentios, honrando religiosamente a seus fingidos e falsos deuses; interiormente, com a confiança que neles punham, e exteriormente, com as imagens em que os adoravam". ${ }^{32}$ Quanto ao catolicismo romano, pondera que:

A outra idolatria consiste em errar o verdadeiro modo de como a Deus, nosso Senhor, se há de servir: quando se finge que a Deus se honra e serve no modo João Correa de Mizquita. Outra, a os P. Agostinhos, de Bemgala. E as Propostas A todos os Eclesiasticos dos Reynos e Senhorios de Portugal... Em Batavia, Por Abrahão Gerardo Kaisero, Anno 1672. British Library of London.

${ }^{32}$ ALMEIDA, op. cit., p. 34.
} 
A literatura religiosa polemista nas Índias Orientais seiscentistas e a elaboração ...

que Ele nunca nos tem mandado; ou, ao contrário, de todo nos tem proibido, a saber, por imagens, figuras, semelhanças e ordenanças inventadas dos homens. ${ }^{33}$

Desse modo, João Ferreira de Almeida coloca em uma mesma categoria analítica - a partir do conceito de "idolatria" - o catolicismo romano e as religiões gentílicas, enfatizando, porém, as peculiaridades de cada um. Almeida afirma, inclusive, ser a segunda forma idolátrica menos grave, por ser motivada por ignorância. Em relação à primeira, considera imperdoável, por conta do conhecimento que os católicos têm das Escrituras.

Cumpre-nos ressaltar, conclusivamente, que as especificidades desse embate doutrinário católico-protestante, ocorrido nas Índias Orientais seiscentistas, devem ser focalizadas de modo que seja possível identificar suas particularidades enquanto processo religioso singular, decorrente de sua ocorrência em um contexto histórico e cultural especial. Não se deve perder de vista, nesse sentido, que, ao transportar-se a cultura europeia para regiões anteriormente a ela inacessíveis, a partir da Idade Moderna, instalou-se também, nessas regiões alcançadas, não uma monolítica e ideal "religiosidade cristã ocidental", mas os seus inerentes conflitos religiosos internos. Assim, a expansão europeia sobre os "novos mundos", potencializada a partir do século XV, deve ser considerada elemento fundamental à compreensão do significado histórico desse processo de tradução bíblica.

Os efeitos culturais da expansão marítima europeia, característica da modernidade, foram, em todos os sentidos, revolucionários. Segundo a avaliação de um historiador português, "no espaço de alguns anos após o descobrimento do caminho marítimo para a Índia, caíram por terra as tradicionais barreiras geográficas que dividiam a humanidade em compartimentos estanques". Como consequência, "os homens começaram então a aperceber-se da verdadeira dimensão e variedade do espaço planetário". ${ }^{34}$ Assim, a intensificação dos encontros interculturais a partir desse período, justamente no contexto das reformas religiosas europeias, marcou indelevelmente o caráter singular da civilização moderna. Nesse período, o duplo encontro com a diferença cultural experimentada no Ocidente - por um lado, com a alteridade histórica, a partir da renovada aproximação filológica com a produção cultural da Antiguidade Clássica, no contexto do Renascimento, e por outro,

\footnotetext{
${ }^{33}$ Ibidem.

${ }^{34}$ LOUREIRO, R. "O encontro de Portugal com a Ásia no século XVI". In: FERRONHA, L. et. al. (coord.). 0 confronto do olhar: o encontro dos povos na época das navegações portuguesas. Lisboa: Caminho, 1991. p. 182-183.
} 
com a alteridade espacial, a partir dos contatos com os povos até então desconhecidos das Índias - conduziu a um singular resultado histórico. ${ }^{35}$

Portanto, como vimos, a diversidade cultural das Índias Orientais, representada pelos inúmeros povos que habitavam os seus territórios antes da chegada dos europeus, foi, de certa maneira, instrumentalizada no embate teológico católico-calvinista, relativo ao contexto de tradução. A cidade de Batávia, onde João Ferreira de Almeida desenvolveu a maior parte de seu trabalho de tradução, era habitada, no século XVII, por uma população miscigenada, composta não somente por holandeses e javaneses, mas também por chineses, malaios, balineses e muitos escravos vindos de outras regiões orientais. ${ }^{36}$ Além disso, o próprio substrato cultural da região apresenta-se bastante complexo, na medida em que "a tradição religiosa indonésia foi caracterizada, antes do domínio holandês no século XVII, pelas raízes milenares de um 'estado hindu-budista javanês', posteriormente alcançado pela islamização". ${ }^{37}$

Ainda assim, o caráter histórico de longa duração que caracteriza o debate cristão em torno da definição de sua ortodoxia - disputas estas que remontam às origens da religião cristã, perpassando toda a sua história permite que seus pontos de referência basilares permaneçam relativamente estáveis, mesmo diante dos mais variados contextos. Assim, por exemplo, as disputas em torno da interpretação correta das Escrituras, da constituição do seu cânon, da tradição eclesiástica, da sucessão apostólica, da salvação extramundana, da predestinação, do culto aos santos, da preeminência de Roma etc., não são exclusividade do conflito católico-protestante moderno, e muito menos de sua ocorrência no além-mar, sendo, antes, recorrentes com as suas devidas particularidades - ao longo da história do cristianismo.

Desse modo, conforme expresso neste artigo - ainda que, por enquanto, apenas preliminarmente - o conflito religioso relativo à tradução bíblica de Almeida contém, evidentemente, um conjunto de traços singulares relacionados ao seu contexto de produção, referentes à expansão global europeia e aos encontros interculturais decorrentes, mas os seus pontos teológicos cardeais permanecem os mesmos em relação ao conflito teológico intraeuropeu. A forma como o contexto histórico é absorvido no embate

\footnotetext{
${ }^{35}$ Essa ideia é bem desenvolvida em AGNOLIN, Ad. Jesuítas e Selvagens: a negociação da fé no encontro catequético-ritual americano-tupi (séculos XVI-XVII). São Paulo: Humanitas/FAPESP, 2007, p. 478 e ss.

${ }^{36}$ ARITONANG, J. S. \& STEENBRINK, K. (eds.). A History of Christianity in Indonesia. Leiden/Boston: Brill, 2008. p. 121.

${ }^{37}$ GEERTZ, C. Observando o Islã. Rio de Janeiro: Jorge Zahar, 2004. p. 24-25.
} 
religioso luso-holandês oriental, tornando-o singular, caracteriza-se sobretudo pela instrumentalização de suas particularidades, visando fortalecer e exemplificar os argumentos teológicos já conhecidos da querela tridentina. Assim, pudemos demonstrar que, no âmago do embate religioso subjacente à elaboração da tradução portuguesa da Bíblia, a experiência de contatos interculturais no Oriente foi utilizada pelos contendores católicos e protestantes para reafirmar suas convicções teológicas. Assim, a maneira como esse contexto de expansão da cultura ocidental incide sobre os conflitos religiosos analisados poderá servir para nos indicar o significado histórico da primeira tradução bíblica em língua portuguesa.

Artigo recebido para publicação em: 31/07/2013

Artigo aprovado para publicação em: 08/11/2013 